\title{
Effects of Gender on Students' Entrepreneurial Intentions: A Theory of Planned Behaviour Perspective
}

\author{
Simon Thabo Mahlaole, Mmakgabo Justice Malebana \\ Department of Management and Entrepreneurship, Tshwane University of Technology, Pretoria, South Africa \\ Email: 214001365@tut4life.ac.za, simonmahlaole@gmail.com, MalebanaMJ@tut.ac.za
}

How to cite this paper: Mahlaole, S. T., \& Malebana, M. J. (2022). Effects of Gender on Students' Entrepreneurial Intentions: A Theory of Planned Behaviour Perspective. Open Journal of Business and Management, 10, 57-76.

https://doi.org/10.4236/ojbm.2022.101004

Received: November 1, 2021

Accepted: December 14, 2021

Published: December 17, 2021

Copyright $\odot 2022$ by author(s) and Scientific Research Publishing Inc. This work is licensed under the Creative Commons Attribution International License (CC BY 4.0).

http://creativecommons.org/licenses/by/4.0/

\begin{abstract}
Based on a sample of 301 first, second and third-year undergrad entrepreneurship students from a university of technology in South Africa, the purpose of this research paper was to investigate the effects of gender on students' entrepreneurial intentions (EI), as well as the determinants of EI. The theory of planned behaviour (TPB) underpins this research. The study's objectives were to establish whether the TPB might assist in explaining the effects of gender on students' EI, as well as the factors that influence EI. The data was analysed using partial least square (PLS) structural equation modeling (SEM) algorithm in SmartPLS 3.3.3. The findings of this study revealed that gender has no significant relationship with students' EI, subjective norms, perceived behavioural control and attitude towards behaviour. In terms of the TPB, the findings revealed that all the antecedents of the TPB have a statistically significant correlation with EI. The findings suggest that the TPB can be regarded as a useful tool for evaluating students' EI.
\end{abstract}

\section{Keywords}

Entrepreneurial Intentions, Theory of Planned Behaviour, Gender

\section{Introduction}

Entrepreneurship is important to every country's economy since it has the potential to encourage job creation, innovation and creativity, as well as high employment, positive social development and economic progress (Shane \& Venkataraman, 2000; Rowley, Baregheh, \& Sambrook, 2011; Nasiru, Keat, \& Bhatti, 2015). South Africa is in critical need of a more dynamic, job-creating, and inventive growth path, especially in the aftermath of the COVID-19 pandemic. 
The unemployment rate in South Africa increased to $34.4 \%$ in the second quarter of 2021 , up from $32.6 \%$ in the first quarter, while the youth unemployment rate grew to $64.40 \%$, up from $63.30 \%$ in the first quarter (Statistics South Africa, 2021). This demonstrates that there is a clear need to support youth entrepreneurship in South Africa by encouraging more young people to see it as a viable career option. Entrepreneurship has a fundamental role in fostering innovation, increasing efficiency, and establishing a corporate culture, and perhaps most crucially, has the ability to create jobs. A higher emphasis on entrepreneurship would allow more businesses to emerge, formalizing many sectors of the South African economy.

Understanding entrepreneurship requires one to understand an individual's entrepreneurial intentions (EI), attitudes and behaviour (Krueger, Reilly, \& Carsrud, 2000; Nasiru, Keat, \& Bhatti, 2015). In general, EI is demarcated as a state of mind that directs an individual's attention, experience and activity towards a specified objective or path to achieving a business goal (Shapero \& Sokol, 1982). The notion of EI encapsulates the traits that can be characterized by a person's attitudes, talents and contextual factors, as well as their psychological qualities (Fini et al., 2009). Being an entrepreneur is clearly a conscious action and having a strong EI can have a huge influence on an individual's intention to starting-up a new business (Tomy \& Pardede, 2020). Nevertheless, gender stereotypes regarding entrepreneurship have also been demonstrated in studies to have a significant impact on people's intentions to become entrepreneurs (Gupta et al., 2009). Despite the fact that many gender disparities in entrepreneurship have been established based on real entrepreneurs, some research studies have attempted to validate these differences at the level of EI (Zhao, Seibert, \& Hills, 2005). According to career models, gender is just a background element that influences job-related processes indirectly through other associated variables (Abele, 2000). Considering this, entrepreneurship may be characterized as a type of planned behaviour that can be examined with the use of EI models (Mueller, 2011).

Prior literature on EI appear to have exhausted the intent of one to become an entrepreneur or engage in entrepreneurial activities. In contrast, two primary theories have been utilized to analyze the intents to become an entrepreneur, particularly amongst university students. These two theories namely are commonly known as the theory of planned behaviour (TPB) (Ajzen, 1991) and the entrepreneurial events model (EEM) (Shapero \& Sokol, 1982). The TPB outperforms other frameworks in terms of analytical power (Díaz-Casero, Hernández-Mogollón, \& Roldán, 2012) and is one of the most widely accepted theories for explaining the cause and effect of EI (Liñán \& Chen, 2009; Mothibi \& Malebana, 2019; Mahlaole \& Malebana, 2021). In view of the aforementioned, this research paper has two objectives, initially, it aims to contribute to the literature on EI by applying the TPB (Ajzen, 1991) to the South African setting. Then, it investigates the effects of gender on perceived behavioural control (PBC), subjective norms ( $\mathrm{SN}$ ) 
and attitudes towards behaviour (ATB) on students' EI to establish a business in the near future. The following is how the rest of this research paper is outlined: Section 2 reviews the literature, establishes the hypotheses and conceptual model; Section 3 describes the research methodologies before presenting the study findings and discussions in Section 4; Finally, Section 5 presents the research's conclusions, limits and recommendations for future research.

\section{Literature Review}

\subsection{Theory of Planned Behaviour}

The TPB is based on Ajzen and Fishein's theory of reasoned action, which they published in 1980 (Ajzen, 1991), and has since evolved into a fundamental model for understanding, predicting, and changing people's social behavior (Ajzen, 2012). The TPB's main goal is to provide a comprehensive and accurate foundation for describing behavioural elements (Ajzen, 1991, 2012). The TPB assumes that people's intentions predict their behaviour (Ajzen, 1991), whereas intention refers to how much effort a person plans to put in to carry out that behaviour in the future (Entrialgo \& Iglesias, 2016). The primary construct of the TPB is an individual's intent to perform a specific behavior (Ajzen, 1991, 2012). It is based on the premise that people make rational decisions and intents, which lead to specific behaviours (Küttim et al., 2014). Intentions and behaviour, according to the TPB, are influenced by three major predictors (Ajzen, 1991). To be more specific, the three predictors that influence intentions, as per the TPB are: ATB, PBC, and SN (Ajzen, 1991). Figure 1 below shows a photographic illustration of the TPB.

The first predictor; ATB, considers a person's positive and negative assessments of various behaviours. The second predictor, SN, indicates the societal pressure on an individual to start up a business (from friends, family, coworkers,

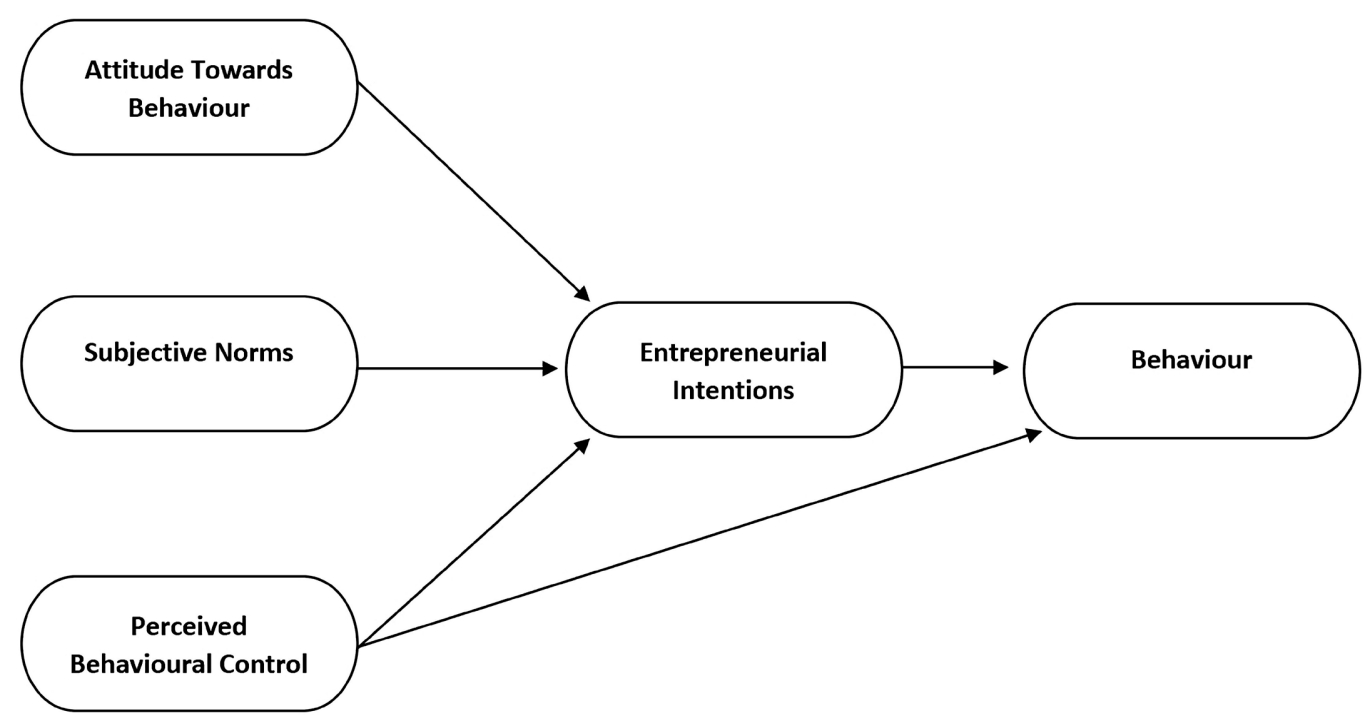

Figure 1. Theory of planned behaviour. Source: Adopted from Ajzen (1991). 
etc.). Finally, $\mathrm{PBC}$ shows a person's skill and capability to perform a particular behaviour (Ajzen, 1991, 2012). The TPB has proven to be a reliable predictor of EI (Armitage \& Conner 2001; Hagger, Chatzisarantis, \& Biddle, 2002; Hussain \& Norashdah, 2015; Tarek, 2017; Marire \& Dhurup, 2018; Mothibi \& Malebana, 2019; Ilman, Ananda, \& Pohan, 2020; Mahlaole \& Malebana, 2021). The stronger an individual's intention to undertake the behaviour under consideration, the more favourable the attitudes and $\mathrm{SN}$, and the larger the $\mathrm{PBC}$, according to $\mathrm{Aj}$ zen (1991). Nonetheless, depending on the behaviour, the importance of ATB, PBC, and SN may vary (Ajzen \& Cote, 2008). Thus, it may be discovered that only attitude has a significant impact on EI, or that both attitude and PBC have a significant impact on EI, or that all three predictors are significant in explaining EI in some cases (Ajzen, 2012; Davids, 2017).

\subsection{Attitude towards Behaviour}

The degree of one's general feelings of favourable or unfavourable toward performing behavior is referred to as their ATB (Ajzen \& Fishbein, 1980). ATB is essentially the result of a set of salient beliefs (known as behavioral beliefs) that executing the behaviour would result in specific outcomes (Ajzen \& Fishbein, 1980; Ajzen, 2012). Consequences might be beneficial or bad, and they can harm either the individual or other parties. As a result, the more favourable the ATB, the more positive the perceived consequence of the behaviour (Ajzen \& Cote, 2008). Empirical research on EI has ATB to be significantly correlated with EI (Samo \& Hashim, 2016; Ebewo, Rugimbana, \& Shambare, 2017; Marire \& Dhurup, 2018; Agollo, Monametsi, \& Phera, 2019; Urban \& Chantson, 2019; Mahmoud et al., 2020; Mahlaole \& Malebana, 2021).

For instance, Ebewo, Rugimbana and Shambare (2017) found that students with a positive ATB are more likely to be entrepreneurs once they have completed their studies. A more recent study by Mahlaole and Malebana (2021) also revealed that ATB is significantly related to students' EI. Samo and Hashim (2016) established the notable importance of ATB as a predictor of student EI. Similar results have also been found by other research studies (Malebana \& Swanepoel, 2015; Naia et al., 2017; Al-Shammari \& Waleed, 2018). Contrary to the abovementioned findings, Bhinekawati, Nelloh and Abdurahman (2020) found no significant effect between EI and students' ATB.

\subsection{Subjective Norms}

$\mathrm{SN}$ is the second predictor of EI. In general, it is an individual's assessment of whether the majority of important individuals to that person believe he or she should or should not engage in the behaviour in question (Ajzen, 1991). According to the theory, the more an individual believes how vital others believe he or she should engage in a behaviour, the more likely the person will intend to do so (Ajzen, 1991, 2007, 2012). SN emerge from an individual's salient ideas (known as normative beliefs) about whether specific groups (colleagues, teachers 
and seniors) believe he or she should engage in certain behaviours (Ajzen 1991, 2007, 2012). A number of studies have found SN to be a significant predictor of students' EI (Hussain \& Norashdah, 2015; Mwiya et al., 2017; Marire \& Dhurup, 2018; Mothibi \& Malebana, 2019; Aga \& Singh, 2020; Mahlaole \& Malebana, 2021) even though others did not support this finding (Davids, 2017; Awan \& Ahmad, 2017; Wibowo, 2019; Paiva et al., 2020; Alshebami et al., 2020; Mahmoud et al., 2020).

Hussain and Norashdah (2015) conducted a study on Pakistan students in Sindh and discovered that SN where significant correlation with EI. Mwiya et al. (2017) along with Aga and Singh (2020) also discovered that SN has a significant positive relation with EI. In South African context, Mothibi and Malebana (2019) revealed that SN has a significant influence on secondary school learners' EI. Similarly, Mahlaole and Malebana (2021) applied the TPB and uncovered that $\mathrm{SN}$ also has a significant effect on students' EI. Contrary to the aforementioned, Davids (2017) found that SN has no significant relationship with EI. Similar findings were also reported by the following studies (Awan \& Ahmad, 2017; Wibowo, 2019; Paiva et al., 2020; Alshebami et al., 2020; Mahmoud et al., 2020).

\subsection{Perceived Behavioural Control}

The efficacy of the control component in either preventing or promoting the behaviour is referred to as PBC (Ajzen, 2007, 2015). PBC assesses the perceived efficacy or difficulty of carrying out the behaviour (Ajzen, 2012). It influences people's decision to seek an objective, as well as their level of preparation, efforts, perseverance, thought, and emotions experienced during the work (Ajzen 1991, 2007, 2012). PBC, according to Ajzen (2012), can indirectly affect behavioural outcomes by influencing intentions to engage in and endure the behaviour in the face of obstacles that develop during execution.

The link between PBC and EI has been validated across several research studies (Malebana, 2014; Malebana \& Swanepoel, 2015; Iglesias-Sánchez et al., 2016; Naia et al., 2017; Galvão, Marques, \& Marques, 2018). For instance, Galvão, Marques and Marques (2018) discovered that students' EI were moderately affected by PBC. In sport sciences, Naia et al. (2017) put Ajzen's TPB to the test to see which variables influenced students' $\mathrm{EI}$ the most. $\mathrm{PBC}$ had a considerable favourable impact on EI, according to their findings (Naia et al., 2017). Furthermore, Malebana and Swanepoel (2015) discovered that PBC, as well as ATB, caused the greatest variation in EI. Shah and Soomro (2017) revealed that PBC had no significant effect on EI among university students in Pakistan, which is surprising and counterintuitive to Ajzen's position and earlier studies on the TPB.

\subsection{Effects of Gender in the Antecedents of Entrepreneurial Intentions}

In analysing EI, gender has a significant role (Robledo et al., 2015). Gender has 
long been considered one of the elements impacting the process of commercializing research findings, according to Miranda et al. (2017). Previous research had shown that gender is significantly related to EI and the determinants of EI in the TPB (Karimi et al., 2014; Malebana \& Swanepoel, 2015; Robledo et al., 2015; Feder \& Niţu-Antonie, 2017; Palupi \& Santoso, 2017). Gender effects in EI can be related to different perceptions of the drivers of EI. For instance, effects on ATB (Liñán, Urbano, \& Guerrero, 2011; Karimi et al., 2014; Maes, Leroy, \& Sels, 2014; Malebana, 2015; Malebana \& Swanepoel, 2015; Robledo et al., 2015; Palupi \& Santoso, 2017) PBC (Liñán, Urbano, \& Guerrero, 2011; Sahinidis, Giovanis, \& Sdrolias, 2012; Karimi et al., 2014; Maes, Leroy, \& Sels, 2014; Santos, Roomi, \& Liñán 2014; Malebana, 2015; Malebana \& Swanepoel, 2015; Robledo et al., 2015; Feder \& Nițu-Antonie, 2017; Palupi \& Santoso, 2017) and SN (Karimi et al., 2014; Malebana, 2015; Malebana \& Swanepoel, 2015; Feder \& Nițu-Antonie, 2017; Palupi \& Santoso, 2017) account for the effects of gender in EI.

Karimi et al. (2014) used the TPB to explore the effect of gender on students and discovered that gender had a significant relationship with ATB, PBC, SN and EI. Malebana and Swanepoel (2015) also discovered that gender had a significant relationship with ATB, PBC, SN and EI. Feder and Niţu-Antonie (2017) discovered that gender had a significant positive influence on PBC, SN and EI, but no significant effect on ATB. Malebana (2015) discovered a significant positive relationship between gender and $\mathrm{PBC}, \mathrm{SN}, \mathrm{ATB}$, and entrepreneurial self-efficacy. Maes, Leroy and Sels (2014) reported that gender had a statistically significant effect on personal attitude and $\mathrm{PBC}$ but found no significant relationship between gender, EI and SN. Robledo et al. (2015) revealed that gender had a significant positive influence on $\mathrm{ATB}, \mathrm{PBC}$ and $\mathrm{EI}$ and an insignificant relationship with SN. Palupi and Santoso (2017) examined the effects of gender on EI through the antecedents proposed by the TPB and revealed that gender had a statistically significant influence on PBC, SN, ATB and EI.

Youth unemployment has a significant detrimental influence on economic growth and efficiency. In the field of entrepreneurship, gender stereotypes and youth unemployment are indeed a persistent problem (Aldrich, 2005). The disparity between male and female entrepreneurs is particularly apparent in high-growth businesses, with women accounting for a substantially smaller percentage of entrepreneurs that are capable of founding and achieving high-growth equity outcomes (Robb, Coleman, \& Stangler, 2014). Gender has been studied as a factor in determining EI in numerous studies. They have often explored the influence of these factors on gender differences, but they have not always gone far enough into the cause and effects of gender particularly in South African context. Hence, it's critical for the researcher to look into the effects of gender on students' EI, as well as the factors that influence EI at a South African university of technology. Existing literature has revealed that the effects of gender can be explained by various antecedents of EI. Though, some research suggests that men and women share far more similarities than differences (Daz-Garca \& 
Jiménez-Moreno, 2010). As a result, the findings of gender and entrepreneurship studies are still divided. In order to improve EI and entrepreneurial activity rates among students, it is critical to instill good entrepreneurial attitudes, improve $\mathrm{PBC}$, and establish socially acceptable norms. Thus, we hypothesize that:

$H_{1}$ : Gender has a statistically significant relationship with EI.

$\mathrm{H}_{2}$ : Gender has a statistically significant relationship with $A T B$.

$H_{3}$ : Gender has a statistically significant relationship with $S N$.

$H_{4}$ : Gender has a statistically significant relationship with PBC.

\subsection{Research Model}

The proposed research model, shown in Figure 2, is based on Ajzen's (1991) TPB, but has been modified to account for the role that gender may play in encouraging students to start their own businesses. The model displays the variables employed in this study as well as their interrelationships. Gender is served as the independent variable while $\mathrm{SN}, \mathrm{ATB}$, and $\mathrm{PBC}$ are served as mediators, whereas EI is served as the dependent variable. Gender, according to the suggested model, has an effect on EI, which is mediated by SN, ATB, and PBC.

\section{Research Methodology}

This study used an online survey questionnaire, as well as a cross-sectional and quantitative research design. A quantitative research design was preferred because it can also be used to support or reject hypotheses at advanced or earlier stages of the research process (Creswell, 2014), and is frequently associated with a deductive research strategy that prioritizes the use of data in theory (Bryman \& Bell, 2015). The population for this study consisted of 1003 first, second, and third year entrepreneurial students enrolled at the Tshwane University of Technology (TUT) in the year 2020. Yamane (1967) recommended using the formula below to determine the sample size for this study.

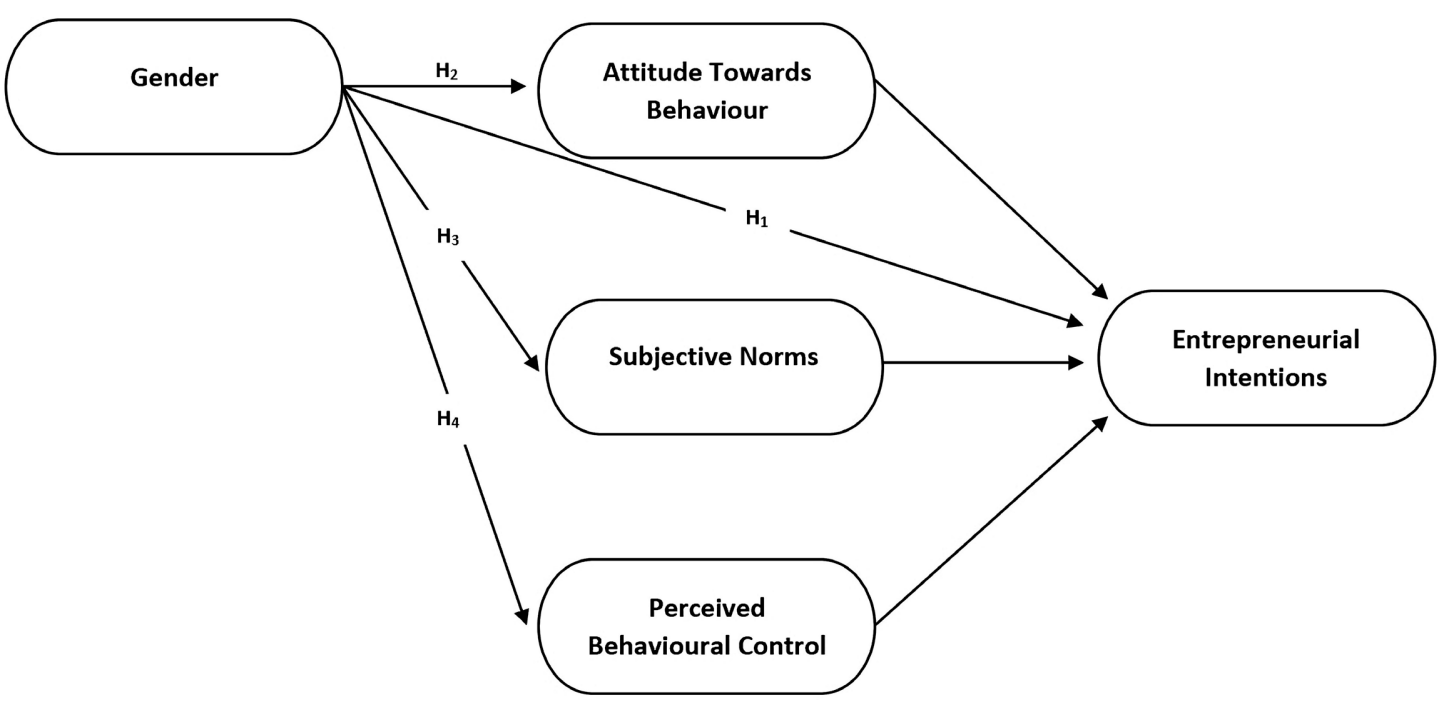

Figure 2. Research model. Source: Adapted from Ajzen (2012) and Malebana (2012). 


$$
n=\frac{N}{1+N(e)^{2}}
$$

whereas $n$ represents the sample size, $N$ denotes the population size, and $e$ denotes the precision level. Once this formula was utilized, the sample size that resulted was as follows:

$$
n=\frac{N}{1+N(e)^{2}}=n=\frac{1003}{1+1003(0.05)^{2}}=286 \text { students }
$$

Thus, with a 95 percent confidence interval and a 5\% margin of error, the proposed sample size for this research was 286 first, second, and third-year undergrad entrepreneurial students. The online survey questionnaire was however completed by a convenience sample of 301 students who were willing to participate in the study out of the total population.

A structured online survey questionnaire based on a previously validated EI questionnaire (Liñán \& Chen, 2009; Malebana, 2012) was used to collect data. No adjustments were made to any of the questions from previous EI questionnaires (Liñán \& Chen, 2009; Malebana, 2012). The key justification for including these items is that they have been validated in other research studies, making the questionnaire more reliable. After getting ethical approval from the TUT Research Ethics Committee, the data was collected. The data collection process started when the researcher asked for and received permission to distribute the online survey questionnaire via WhatsApp Messenger, using a Google Forms survey hyperlink. An entrepreneurship educator from TUT aided the researcher by giving contact information for class reps, granting access to three WhatsApp Messenger groups made up completely of TUT entrepreneurial students. Due to how straightforward the online survey questionnaire was to understand and the researcher reposting the online survey questionnaire on a daily basis for three weeks on WhatsApp Messenger, the researcher was able to retrieve a large volume of positive responses.

\section{Data Analysis}

The data from the online survey was captured in Microsoft Excel via a spreadsheet and analysed using partial least square (PLS) structural equation modeling (SEM) in SmartPLS 3.3.3. The demographic profile of respondents was analysed using descriptive statistics and the relationship between the dependent and independent variable were examined using PLS-SEM.

\subsection{Demographic Profile of Respondents}

Males' students made up $49.2 \%$ of the respondents, while females made up $44.9 \%$, and $6 \%$ did not specify their gender. $31.2 \%$ of the respondents were between the ages of 18 and $21,42.9 \%$ were between the ages of 21 and 23, and $25.9 \%$ were aged 24 and above. $31.2 \%$ were first-year students, $34.2 \%$ were second-year students, and $34.6 \%$ were third-year students, according to their 
academic level. The profile of respondents is shown in Table 1.

\subsection{Assessment of Measurement Model}

The research measurement model was assessed using the PLS algorithm in SmartPLS 3.3.3. The measurement model was evaluated using factor loadings, Cronbach's alpha, composite reliability, average variance extracted, convergent validity and discriminant validity. The proportion of indicator variation explained by the latent variable is referred to as indicator reliability (Asgari, 2016). Manifest variables with outer loadings of 0.7 or higher are deemed highly satisfactory (Hair et al., 2017) whereas 0.5 is considered adequate. Outer loadings of 0.4 should be acceptable (Hulland, 1999), however Henseler, Ringle and Sarstedt (2016) recommend that manifest variables with $\mathrm{m}$ between 0.4 and 0.7 be considered for deletion. If omitting these indicators improves the composite reliability, they should indeed be dropped. Figure 2 depicts the conceptual model's outer loadings for manifest variables with loadings greater than 0.7. Table 2 below shows that these loadings are deemed highly satisfactory and indicate that the individual item reliability requirement has been met successfully.

For constructs to be considered internally consistent, Cronbach Alpha values of more than 0.7 are required (Hair et al., 2017). Table 2 shows that all four constructs have a Cronbach Alpha value of greater than 0.7, indicating that they are internally consistent. For the constructs to be internally consistent, the measurement model's composite reliability values should be greater than 0.8 (Hair et al., 2017). As demonstrated in Table 2, all variables included in this study had composite reliability values more than 0.8 . The fact that all of these values are greater than 0.8 implies that these six variables are internally consistent. The

Table 1. Profile of respondents.

\begin{tabular}{cccc}
\hline Variables & Description & Frequency & Percentage \\
\hline \multirow{3}{*}{ Gender } & Male & 148 & 49.2 \\
& Female & 135 & 44.9 \\
& Not Disclosed & 18 & 6 \\
& Total & 301 & 100 \\
\hline \multirow{3}{*}{ Age } & $18-20$ & 94 & 31.2 \\
& $21-23$ & 129 & 42.9 \\
& $24-$ Above & 78 & 25.9 \\
Entrepreneurship & Total & 301 & 100 \\
Education Level of Study & First Year & 94 & 31.2 \\
& Second Year & 103 & 34.2 \\
& Third Year & 104 & 34.6 \\
& Total & 301 & 100 \\
\hline
\end{tabular}

Source. Microsoft Excel generated from online questionnaire data for this study. 
Table 2. Factor loadings, reliability and validity of construct.

\begin{tabular}{cccccc}
\hline Items & 1 & 2 & 3 & 4 & 5 \\
\hline Gender & 1.000 & & & \\
\hline Entrepreneurial Intentions & & & & \\
EI2 & & 0.845 & \\
EI3 & 0.866 \\
EI4 & 0.877 \\
EI5 & & 0.903 & \\
EI6 & & 0.911 & \\
\hline
\end{tabular}

\section{Attitude towards Behaviour}

$\begin{array}{ll}\text { ATB1 } & 0.790 \\ \text { ATB2 } & 0.845 \\ \text { ATB3 } & 0.759 \\ \text { ATB4 } & 0.846 \\ \text { ATB5 } & 0.803 \\ \text { ATB6 } & 0,722\end{array}$

\section{Subjective Norms}

$\begin{array}{ll}\text { SN1 } & 0.834 \\ \text { SN2 } & 0.785 \\ \text { SN3 } & 0.788 \\ \text { SN4 } & 0.825 \\ \text { SN5 } & 0.759 \\ \text { SN6 } & 0.810\end{array}$

\section{Perceived Behavioural Control}

\begin{tabular}{|c|c|c|c|c|c|}
\hline $\mathrm{PBC} 2$ & & & & & 0.819 \\
\hline PBC3 & & & & & 0.836 \\
\hline PBC5 & & & & & 0.830 \\
\hline PBC7 & & & & & 0.841 \\
\hline PBC8 & & & & & 0.855 \\
\hline PBC9 & & & & & 0.722 \\
\hline Cronbach's Alpha & 1.000 & 0.928 & 0.884 & 0.889 & 0.901 \\
\hline Composite Reliability & 1.000 & 0.945 & 0.912 & 0.915 & 0.924 \\
\hline Average Variance Extracted & 1.000 & 0.775 & 0.633 & 0.641 & 0.670 \\
\hline
\end{tabular}

Source. SmartPLS generated from online questionnaire data for this study.

average variance extracted is a parameter for determining convergent validity ( $\mathrm{Ra}$ vand \& Baghei, 2016). For a concept to have adequate convergent validity, it must have a score of at least 0.5 (Fornell \& Larcker, 1981). Table 2 shows that 
the average variance extracted values for all of the variables in this research were greater than 0.5 , signifying good convergent validity.

In order to attain discriminant validity, the square root of the average variance extracted value must be higher than the square correlation with other structures (Fornell \& Larcker, 1981). As indicated in Table 3, discriminant validity has been achieved, and the latent structure's correlation has been compared to the square root of the average variance extracted (Fornell \& Larcker, 1981).

According to Hair et al. (2017), two methods for testing discriminant validity are the Fornell-Larcker criterion and the cross loading heterotrait-monotrait (HTMT) ratio. The HTMT criterion was also used in this study due to the inadequacies of the Fornell-Larcker criterion; as a result, we used the HTMT ratio as advised by Henseler, Ringle, and Sinkovics (2009). Table 4 demonstrates that HTMT values are lower than the fundamental assumption of 0.85 , implying that discriminant validity concerns are not present.

\subsection{Assessment of Structural Model}

The proposed structural model was analysed once the validity and reliability of the measurement model have been assessed (Figure 3). $\mathrm{R}^{2}$ value assessment by PLS is also known as coefficient of determination $\left(R^{2}\right)$. The $R^{2}$ of endogenous latent variables should be higher than 0.26 for a good model, according to Chuan and Penyelidikan (2006). Hair et al. (2017) considered $\mathrm{R}^{2}$ values of $0.75,0.50$, and 0.25 for the dependent variables to be significant, moderate, and weak, respectively. The cumulative effect of factors on the endogenous latent variable EI

Table 3. Fornell-Larcker criterion.

\begin{tabular}{cccccc}
\hline Items & $\mathbf{1}$ & $\mathbf{2}$ & $\mathbf{3}$ & $\mathbf{4}$ & $\mathbf{5}$ \\
\hline Gender & $\mathbf{1 . 0 0 0}$ & & & & \\
Entrepreneurial Intentions & -0.048 & $\mathbf{0 . 8 8 1}$ & & & \\
Attitude Towards behaviour & -0.025 & 0.753 & $\mathbf{0 . 7 9 5}$ & & \\
Subjective Norms & 0.084 & 0.430 & 0.404 & $\mathbf{0 . 8 0 1}$ & \\
Perceived Behavioural Control & 0.008 & 0.654 & 0.589 & 0.343 & $\mathbf{0 . 8 1 8}$ \\
\hline
\end{tabular}

Source. SmartPLS generated from online questionnaire data for this study.

Table 4. Heterotrait-Monotrait ratio (HTMT).

\begin{tabular}{cccccc}
\hline Items & $\mathbf{1}$ & $\mathbf{2}$ & $\mathbf{3}$ & $\mathbf{4}$ & $\mathbf{5}$ \\
\hline Gender & & & & & \\
Entrepreneurial Intentions & 0.050 & & & & \\
Attitude Towards behaviour & 0.089 & 0.811 & & & \\
Subjective Norms & 0.093 & 0.459 & 0.430 & & \\
Perceived Behavioural Control & 0.032 & 0.711 & 0.650 & 0.376 & \\
\hline
\end{tabular}

Source. SmartPLS generated from online questionnaire data for this study. 


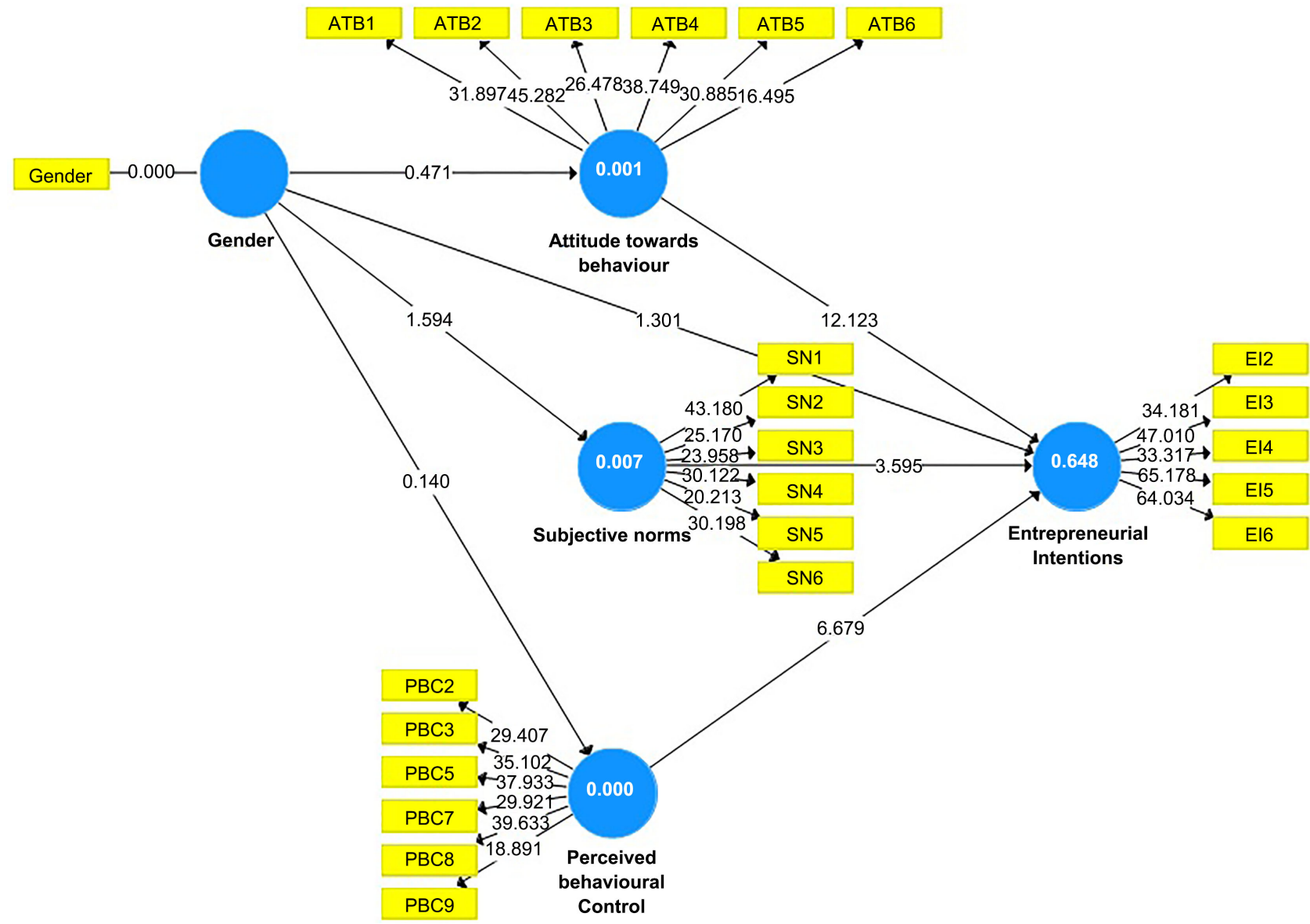

Figure 3. Structural model output.

in this study is 0.648 , indicating that the variables have a positive overall impact. A structural model assessment was used to evaluate the relationship between latent constructs and to validate the conceptual model (Hair et al., 2017). Following the assessment of the measurement model, the research explored the structural model by performing a PLS Bootstrapping on 5000 replicates to determine the significance of the path coefficient (Ringle, Wende, \& Becker, 2015; Hair et al., 2017). The full estimates of the structural equation model are shown in Figure 3.

To investigate the significance of the structural relationships, the path coefficients and their respective significance levels were evaluated. Table 5 below shows that gender has no statistically significant relationship with $\mathrm{PBC}$, attitude toward behavior, SN, or EI, according to Table 5. The findings imply that gender has no effect or plays no significant role in students' intentions to establish a business in the future. These findings do not provide support for the proposed study hypothesis and therefore. $\mathrm{H}_{1}, \mathrm{H}_{2}, \mathrm{H}_{3}$ and $\mathrm{H}_{4}$ are rejected. Table 5 further illustrates that PBC $(\beta=0.305, p<0.05), \mathrm{SN}(\beta=0.117, p<0.05)$ and ATB $(\beta=$ $0.525, p<0.05)$ has a statistically significant and positive correlation with EI. The findings suggest that the TPB can be regarded as a valuable tool for evaluating students' EI. 
Table 5. Path coefficient.

\begin{tabular}{ccccccc}
\hline Path & $\begin{array}{c}\text { Path } \\
\text { Coefficent }\end{array}$ & Mean & $\begin{array}{c}\text { Standard } \\
\text { Deviation }\end{array}$ & T Statistics & $\begin{array}{c}P \text { Value } \\
\begin{array}{c}\text { Significant } \\
\text { Level }\end{array}\end{array}$ \\
\hline Gender -> EI & -0.047 & -0.047 & 0.036 & 1.301 & 0.193 & n.s \\
Gender -> ATB & -0.025 & -0.025 & 0.054 & 0.471 & 0.638 & n.s \\
Gender -> PBC & 0.084 & 0.084 & 0.052 & 1.594 & 0.111 & n.s \\
Gender -> PBC & 0.008 & 0.007 & 0.054 & 0.140 & 0.888 & n.s \\
ATB -> EI & $0.525^{* * *}$ & 0.524 & 0.043 & 12,123 & 0.000 & $* * *$ \\
SN -> EI & $0.117^{* * *}$ & 0.118 & 0.033 & 3.595 & 0.000 & $* * *$ \\
PBC -> EI & $0.305^{* * *}$ & 0.307 & 0.046 & 6.679 & 0.000 & $* * *$ \\
\hline
\end{tabular}

${ }^{\star} p<0.05,{ }^{* *} p<0.01,{ }^{* *} p<0.001$.

\section{Conclusions, Implication, Limitations and Recommendations}

\subsection{Discussion and Conclusions}

Concern regarding the generalization of findings from previous studies due to constraints and the current youth unemployment rates prompted the creation of this study. The purpose of this research paper was to examine the influence of gender on EI among entrepreneurship students at a South African university of technology. The findings of this paper revealed that gender has no statistically significant relationship with the antecedents of the TPB, namely, SN, ATB, PBC and EI. These findings suggest that entrepreneurial students' intentions to establish a business in the near future are unaffected by their gender. These findings are consistent with those of previous research studies which discovered that gender has no bearing on students' EI (Maes, Leroy, \& Sels, 2014; Mothibi \& Malebana, 2019), SN (Maes, Leroy, \& Sels, 2014; Robledo et al., 2015; Mothibi \& Malebana, 2019), PBC (Mothibi \& Malebana, 2019) and ATB (Feder \& Nițu-Antonie, 2017; Mothibi \& Malebana, 2019). Nevertheless, the findings of this paper contradicted those of previous research studies, which found that gender is statistically significantly related to PBC, ATB SN and EI (Karimi et al., 2014; Malebana, 2015; Malebana \& Swanepoel, 2015; Palupi \& Santoso, 2017).

The findings of this research further revealed that EI has a significant relationship with all the antecedents of the TPB. These findings supported those of prior research which uncovered that $\mathrm{SN}, \mathrm{ATB}$, and $\mathrm{PBC}$ had a significant correlation with EI (Hussain \& Norashdah, 2015; Tarek, 2017; Marire \& Dhurup, 2018; Mothibi \& Malebana, 2019; Ilman, Ananda, \& Pohan, 2020; Mahlaole \& Malebana, 2021). The findings suggest that the TPB is a useful tool for evaluating students' EI. Even so, the findings contradict those of preceding studies which revealed that SN (Awan \& Ahmad, 2017; Davids, 2017; Wibowo, 2019; Paiva et al. 2020; Alshebami et al., 2020; Mahmoud et al., 2020), ATB (Bhinekawati, Nelloh, \& Abdurahman, 2020) and PBC (Shah \& Soomro, 2017) have an insignificant relationship with EI. 


\subsection{Implications for Policymakers}

The study paper's conclusions have important ramifications for policymakers, both theoretically and practically. The findings of this study revealed that gender has no significant influence on students' EI and the antecedents of the TPB, suggesting that gender has no bearing on whether an individual will become an entrepreneur or establish a business in the future. Hence, policymakers should actively support equality in entrepreneurship and promote equal opportunities for both male and female students. Policymakers must also keep working to eliminate barriers that male and female students experience during entrepreneurship and many other career opportunities, while still acknowledging that providing equal opportunities to men and women is a required but unsatisfactory condition for promoting gender equality throughout entrepreneurship (Vracheva \& Stoyneva, 2020). Furthermore, policymakers should consider offering financial support to potential individuals and groups in the form of subsidies and grants to entrepreneurs in order to help them launch new enterprises that would inevitably stimulate the economy. Policymakers should provide a plethora of solutions to facilitate this process (Terjesen \& Amoros, 2010).

\subsection{Limitations and Recommendations for Future Research}

This research paper has some limitations which are the basis for recommendations in relation to the foundation for future research initiatives, for starters, this paper's main focus was to evaluate the effects of gender on students EI, thus neglecting to evaluate the significant levels of gender differences between male and female students. Future scholars should consider conducting a multi-group analysis to determine the effects of gender and gender differences on students EI in a South African context. Secondly, because this research study was cross sectional in design, it only provides a picture of the research setting, In the future, a longitudinal study is required to better grasp the shift and effects of gender on students' intentions to start a business. Thirdly, the research study was based on a convenient sample of students from TUT. To strengthen the generalizability of the conclusions, more universities from the country (South Africa) should be included in future research studies. Last but not least, the participants in this study were TUT students enrolled in an undergraduate entrepreneurship program. The perspectives of students enrolled in other TUT programs were not considered in this study. The findings were confined to first, second and third-year entrepreneurial students' perspectives. In order to generalize the findings of this study, future scholars should consider conducting a comparative study in other South African universities.

\section{Acknowledgements}

The researchers would like to thank an anonymous reference for his continued support and insightful suggestion. 


\section{Conflicts of Interest}

The authors declare no conflicts of interest regarding the publication of this paper.

\section{References}

Abele, A. E. (2000). A Dual-Impact Model of Gender and Career-Related Processes. In T. Eckes, \& H. M. Trautner (Eds.), The Developmental Social Psychology of Gender (pp. 361-388). Lawrence Erlbaum Associates.

Aga, M. K., \& Singh, A. (2020). Predicting Entrepreneurial Intentions of Students in Ethiopian Public Universities using The Theory of Planned Behaviour. Studies in Indian Place Names, 40, 2377-2386.

Agollo, J. E., Monametsi, G. L., \& Phera, P. (2019). Antecedents of Entrepreneurial Intentions amongst Business Students in a Tertiary Institution. Asia Pacific Journal of Innovation and Entrepreneurship, 13, 138-152. https://doi.org/10.1108/APJIE-06-2018-0037

Ajzen, I. (1991). The Theory of Planned Behavior. Organizational Behavior and Human Decision Processes, 50, 179-211. https://doi.org/10.1016/0749-5978(91)90020-T

Ajzen, I. (2007). Attitudes, Personality, and Behaviours (2nd ed.). McGraw-Hill Education.

Ajzen, I. (2012). The Theory of Planned Behaviour, In P. A. M. Lange, A. W. Kruglanski, \& E. T. Higgins (Eds.), Handbook of Theories of Social Psychology (pp. 438-459). Sage. https://doi.org/10.4135/9781446249215.n22

Ajzen, I. (2015). Consumer Attitudes and Behaviour: The Theory of Planned Behaviour Applied to Food Consumption Decisions. Rivista Di Economia Agraria, 70, 121-138.

Ajzen, I., \& Cote, N. G. (2008). Attitudes and the Prediction of Behaviour. In W. D. Crano, \& R. Prislin (Eds.). Attitudes and Attitude Change (pp. 289-311). Psychology Press.

Ajzen, I., \& Fishbein, M. (1980). Understanding Attitudes and Predicting Social Behaviour. Prentice-Hall Inc.

Aldrich, H. E. (2005). Entrepreneurship. In N. J. Smelser, \& R. Swedberg (Eds.), The Handbook of Economic Sociology (2nd ed., pp. 451-477). Princeton University Press.

Al-Shammari, M., \& Waleed, R. (2018). Entrepreneurial Intentions of Private University Students in the Kingdom of Bahrain. International Journal of Innovation and Science, 10, 43-57. https://doi.org/10.1108/IJIS-06-2017-0058

Alshebami, A. S., Al-Jubari, I., Alyoussef, I. Y., \& Raza, M. (2020). Entrepreneurial Education as a Predicator of Community College of Abqaiq Students' Entrepreneurial Intention. Management Science Letters, 10, 3605-3612.

https://doi.org/10.5267/j.msl.2020.6.033

Armitage, C. J., \& Conner, M. (2001). Efficacy of the Theory of Planned Behaviour: A Meta Analytic Review. British Journal of Social Psychology, 40, 471-499.

https://doi.org/10.1348/014466601164939

Asgari, A. (2016). Introduction to Structural Equation Modeling Partial Least Squares (SEM-PLS).

https://www.slideshare.net/pallobby/introduction-to-structural-equation-modeling-par tia

Awan, N., \& Ahmad, N. (2017). Intentions to Become an Entrepreneur: Survey from University of Karachi. International Journal of Business, Economics and Law, 13, 19-27. https://doi.org/10.2139/ssrn.3037459 
Bhinekawati, R., Nelloh, L. A. M., \& Abdurahman, O. (2020). The Analysis of Entrepreneurial Intention in Rural Area: A Case Study of Bukit Peramun Geosites in Indonesia. Geojournal of Tourism and Geosites, 28, 80-94. https://doi.org/10.30892/gtg.28106-453

Bryman, A., \& Bell, E. (2015). Business Research Methods (4th ed.). Oxford University Press.

Chuan, C. L., \& Penyelidikan J. (2006). Sample Size of Estimation using Krejcie and Morgan and Cohen Statistical Power Analysis: A Comparison. Jurnal Penyelidikan, 7, 78-86.

Creswell, J. W. (2014). Research Design: Qualitative, Quantitative, and Mixed Methods Approaches (4th ed.). Sage Publications.

Davids, F. (2017). The Theory of Planned Behaviour and the Entrepreneurial Event Model as Predictive Models of Entrepreneurial Intention. Master's Thesis, University of Cape Town.

Díaz-Casero, J. C., Hernández-Mogollón, R., \& Roldán, J. L. (2012). A Structural Model of the Antecedents to Entrepreneurial Capacity. International Small Business Journal, 30, 850-872. https://doi.org/10.1177/0266242610385263

Díaz-García, M. C., \& Jiménez-Moreno, J. (2010). Entrepreneurial Intention: The Role of Gender. International Entrepreneurship and Management Journal, 6, 261-283. https://doi.org/10.1007/s11365-008-0103-2

Ebewo, P. E., Rugimbana, R., \& Shambare, R. (2017). Effects of Entrepreneurship Education on Students' Entrepreneurial Intentions: A Case of Botswana. Management Studies, 5, 278-289. https://doi.org/10.17265/2328-2185/2017.04.002

Entrialgo, M., \& Iglesias, V. V. (2016). The Moderating Role of Entrepreneurship Education on the Antecedents of Entrepreneurial Intention. International Entrepreneurship and Management Journal, 12, 1209-1232. https://doi.org/10.1007/s11365-016-0389-4

Feder, E. Z., \& Nițu-Antonie, R. D. (2017). Connecting Gender Identity, Entrepreneurial Training, Role Model and Intentions. International Journal of Gender and Entrepreneurship, 9, 87-108. https://doi.org/10.1108/IJGE-08-2016-0028

Fini, R., Grimaldi, R., Marzocchi, G. L., \& Sobrero, M. (2009). The Foundation of Entrepreneurial Intention. In Summer Conference (pp. 17-19). Frederiksberg, Denmark.

Fornell, C., \& Larcker, D. F. (1981). Evaluating Structural Equation Models with Unobservable Variables and Measurement Error. Journal Marketing Research, 18, 375-381. https://doi.org/10.1177/002224378101800313

Galvão, A., Marques, C. S., \& Marques, C. P. (2018). Antecedents of Entrepreneurial Intentions among Students in Vocational Training Programmes. Education + Training, 60, 719-734. https://doi.org/10.1108/ET-03-2017-0034

Gupta, V. K., Turban, D. B., Wasti, S. A., \& Sikdar, A. (2009). The Role of Gender Stereotypes in Perceptions of Entrepreneurs and Intentions to Become an Entrepreneur. Entrepreneurship Theory and Practice, 33, 397-417. https://doi.org/10.1111/j.1540-6520.2009.00296.x

Hagger, M. S., Chatzisarantis, N. L. D., \& Biddle, S. J. H. (2002). A Meta-Analytic Review of the Theories of Reasoned Action and Planned Behavior in Physical Activity: Predictive Validity and the Contribution of Additional Variables. Journal of Sport and Exercise Psychology, 24, 3-32. http://hdl.handle.net/20.500.11937/10206 https://doi.org/10.1123/jsep.24.1.3

Hair, J. F., Hult, G. T. M., Ringle, C. M., \& Sarstedt, M. (2017). A Primer on Partial Least Squares Structural Equation Modelling (PLS-SEM) (2nd ed.). SAGE Publications. https://doi.org/10.15358/9783800653614 
Henseler, J., Ringle, C. M., \& Sarstedt M. (2016). Using Partial Least Squares Path Modeling in Advertising Research: Basic Concepts and Recent Issues. In S. Okazaki (Ed.), Handbook of Research on International Advertising (pp. 252-276). Edward Elgar.

Henseler, J., Ringle, C. M., \& Sinkovics, R. R. (2009). The Use of Partial Least Squares Path Modelling in International Marketing. In R. R. Sinkovics, \& P. N. Ghauri (Eds.), New Challenges to International Marketing (Vol. 20, pp. 277-319). Emerald Group Publishing Limited. https://doi.org/10.1108/S1474-7979(2009)0000020014

Hulland, J. (1999). Use of Partial Least Squares (PLS) in Strategic Management Research: A Review of Four Recent Studies. Strategic Management Journal, 20, 195-204. https://doi.org/10.1002/(SICI)1097-0266(199902)20:2\%3C195::AID-SMJ13\%3E3.0.CO; $\underline{2-7}$

Hussain, A., \& Norashidah, D. (2015). Impact of Entrepreneurship Education on Entrepreneurial Intentions of Pakistani Students. Journal of Entrepreneurship and Business Innovation, 2, 43-53. https://doi.org/10.5296/jebi.v2i1.7534

Iglesias-Sánchez, P. P., Jambrino-Maldonado, C., Velasco, A. P., \& Kokash, H. (2016). Impact of Entrepreneurship Programmes on University Students. Education + Training, 58, 209-228. https://doi.org/10.1108/ET-01-2015-0004

Ilman, A. H., Ananda, N. A., \& Pohan, A. S. (2020). Entrepreneurial Education and University toward Students' Entrepreneurial Intention. International Journal of Innovative Science and Research Technology, 5, 1271-1278.

Karimi, S., Biemans, H. J. A., Lans, T. Chizari, M., \& Mulder, M. (2014). Effects of Role Models and Gender on Students' Entrepreneurial Intentions. European Journal of Training and Development, 38, 694-770. https://doi.org/10.1108/EJTD-03-2013-0036

Krueger, N. F., Reilly, M. D., \& Carsrud, A. L. (2000). Competing Models of Entrepreneurial Intentions. Journal of Business Venturing, 15, 411-432. https://doi.org/10.1016/S0883-9026(98)00033-0

Küttim, M., Kallaste, M., Venesaar, U., \& Kiis, A. (2014). Entrepreneurship Education at University Level and Students' Entrepreneurial Intentions. Procedia-Social and Behavioral Sciences, 110, 658-668. https://doi.org/10.1016/j.sbspro.2013.12.910

Liñán, F., \& Chen, Y. W. (2009). Development and Cross-Cultural Application of a Specific Instrument to Measure Entrepreneurial Intentions. Entrepreneurship Theory and Practice, 33, 593-617. https://doi.org/10.1111/j.1540-6520.2009.00318.x

Liñán, F., Urbano, D., \& Guerrero M. (2011). Regional Variations in Entrepreneurial Cognitions: Start-Up Intentions of University Students in Spain. Entrepreneurship and Regional Development, 23, 187-215. https://doi.org/10.1080/08985620903233929

Maes, J., Leroy, H., \& Sels, L. (2014). Gender Difference in Entrepreneurial Intentions: A TPB Multi-Group Analysis at Factor and Indicator Level. European Management Journal, 32, 784-794. https://doi.org/10.1016/j.emj.2014.01.001

Mahlaole, S. T., \& Malebana, M. J. (2021). The Effects of Entrepreneurship Educations on Students' Entrepreneurial Intentions at a South African University of Technology. Journal of Entrepreneurship Education, 24, 1-16.

Mahmoud, M. A., Garba, A. S., Abdullah, Y. A., \& Ali, A. I. (2020). Assessment of Entrepreneurship Education on the Relationship Between Attitude Subjective Norms, Perceived Behavioural Control and Entrepreneurial Intention. International Journal of Business and Technopreneurship, 10, 197-210.

http://dspace.unimap.edu.my/xmlui/handle/123456789/67076

Malebana, M. J. (2012). Entrepreneurial Intent of Final-Year Commerce Students in the Rural Provinces of South Africa. Doctor of Commerce Thesis, University of South 
Africa.

Malebana, M. J. (2014). Entrepreneurial Intentions of South African Rural University Students: A Test of the Theory of Planned Behavior. Journal of Economics and Behavioural Studies, 6, 130-143. https://doi.org/10.22610/jebs.v6i2.476

Malebana, M. J. (2015). Gender Differences in Entrepreneurial Intention in the Rural Provinces of South Africa. Journal of Contemporary Management, 12, 615-637. https://hdl.handle.net/10520/EJC175051

Malebana, M. J., \& Swanepoel, E. (2015). Graduate Entrepreneurial Intentions in the Rural Provinces of South Africa. Southern African Business Review, 19, 89-111.

Marire, E., \& Dhurup, M. (2018). Antecedents of Entrepreneurial Intent: A Cross-Country Comparisons of Generation Y University Students. Journal of Review on Global Economics, 7, 195-206. https://doi.org/10.6000/1929-7092.2018.07.18

Miranda, F., Chamorro-Mera, A., Rubio, S., \& Perez-Mayo, J. (2017). Academic Entrepreneurial Intentions: The Role of Gender. International Journal of Gender and Entrepreneurship, 9, 66-86. https://doi.org/10.1108/IJGE-10-2016-0037

Mothibi, N. H., \& Malebana, M. J. (2019). Determinants of Entrepreneurial Intentions of Secondary School Learners in Mamelodi, South Africa. Academy of Entrepreneurship Journal, 25, 1-15.

Mueller, S. (2011). Increasing Entrepreneurial Intention: Effective Entrepreneurship Course Characteristics. International Journal of Entrepreneurship and Small Business, 13, 55-74. https://doi.org/10.1504/IJESB.2011.040416 https://www.inderscienceonline.com/doi/abs/10.1504/IJESB.2011.040416

Mwiya, B., Wang, Y., Shikaputo, C., Kaulungombe, B., \& Kayekesi, M. (2017). Predicting the Entrepreneurial Intentions of University Students: Applying the Theory of Planned Behaviour in Zambia, Africa. Open Journal of Business and Management, 5, 592-610. https://doi.org/10.4236/ojbm.2017.54051

Naia, A., Baptista, R., Biscaia, R., Januário, C., \& Trigo, V. (2017). Entrepreneurial Intentions of Sport Sciences Students and Theory of Planned Behaviour. Motriz: Revista De Educação Física, 23, 14-21. https://doi.org/10.1590/s1980-6574201700010003

Nasiru, A., Keat, O. Y., \& Bhatti, M. A. (2015). Influence Of Perceived University Support, Perceived Effective Entrepreneurship Education, Perceived Creativity Disposition, Entrepreneurial Passion for Inventing and Founding on Entrepreneurial Intention. Mediterranean Journal of Social Sciences, 6, 88-95.

Paiva, L. E. B., Sousa, E. S., Lima, T. C. B., \& Silva, D. (2020). Planned Behaviour and Religious Beliefs as Antecedents to Entrepreneurial Intentions: A Study with University Students. Human and Social Management, 21, 1-27. https://doi.org/10.1590/1678-6971/eramg200022

Palupi, D., \& Santoso, B. H. (2017). An Empirical Study on the Theory of Planned Behaviour. The Effects of Gender on Entrepreneurial Intentions. Journal of Economics, Business and Accountancy Ventura, 20, 71-79. https://doi.org/10.14414/jebav.v20i1.626

Ravand, H., \& Baghaei P. (2016). Partial Least Squares Structural Equation Modelling with R. Practical Assessment, Research and Evaluation, 21, 1-16.

Ringle, C. M., Wende, S., \& Becker, J. M. (2015). SmartPLS 3. SmartPLS Gmbh. http://www.smartpls.com

Robb, A., Coleman, S., \& Stangler, D. (2014, November). Sources of Economic Hope: Women's Entrepreneurship. https://doi.org/10.2139/ssrn.2529094 http://www.kauffman.org/ /media/kauffman org/research\%20reports\%20and\%20cove $\underline{\text { rs/2014/11/sources of economic hope womens entrepreneurship.pdf }}$ 
Robledo, J. L. R., Aran, M. V., Sanchez, V. M., \& Molina, M. A. R. (2015). The Moderating Role of Gender on Entrepreneurial Intentions: A TPB Perspective. Intangible Capital, 11, 92-117. https://doi.org/10.3926/ic.557

Rowley, J., Baregheh, A., \& Sambrook, S. (2011). Towards an Innovation-Type Mapping Tool. Management Decision, 49, 73-86 https://doi.org/10.1108/00251741111094446

Sahinidis A, Giovanis A. N., \& Sdrolias L. (2012). The Role of Gender on Entrepreneurial Intention among Students: An Empirical Test of the Theory of Planned Behaviour in a Greek University. International Journal on Integrated Information Management, 1, 61-79.

Samo, A. H., \& Hashim, N. (2016). The Impact of Entrepreneurial Alertness on Entrepreneurial Intentions. Journal of International Business Research and Marketing, 1, 7-11. https://doi.org/10.18775/jibrm.1849-8558.2015.16.3001

Santos, F. J., Roomi, M. A., \& Liñán, F. (2014). About Gender Differences and the Social Environment in the Development of Entrepreneurial Intentions. Journal of Small Business Management, 54, 49-66. https://doi.org/10.1111/jsbm.12129

Shah, H., \& Soomro, B. A. (2007). Investigating Entrepreneurial Intention among Public Sector University Students of Pakistan. Education and Training, 59, 841-855. https://doi.org/10.1108/ET-11-2016-0168

Shane, S., \& Venkataraman, S. (2000). The Promise of Entrepreneurship as a Field of Research. Academy of Management Review, 25, 217-226. https://doi.org/10.5465/amr.2000.2791611

Shapero, A., \& Sokol, L. (1982). The Social Dimensions of Entrepreneurship. In D. S. C. Kent, \& K. Vesper (Eds.), The Encyclopedia of Entrepreneurship (pp. 72-90). Prentice Hall.

Statistics South Africa (2021, August 24). Labour Force Survey. Quarter 2: 2021. http://www.statssa.gov.za/publications/P0211/Media\%20release\%20QLFS\%20Q2\%202 021.pdf

Tarek, B. A. (2017). University and Entrepreneurship: An Empirical Investigation in the Tunisian Context. International Review of Management and Marketing, 7, 76-84.

Terjesen, S., \& Amoros, J. E. (2010). Female Entrepreneurship in Latin America and the Caribbean: Characteristics, Drivers and Relationship to Economic Development. European Journal of Development Research, 22, 313-330.

https://doi.org/10.1057/ejdr.2010.13

Tomy, S., \& Pardede, E. (2020). An Entrepreneurial Intention Model Focusing on Higher Education. International Journal of Entrepreneurial Behavior and Research, 26, 1423-1447. https://doi.org/10.1108/IJEBR-06-2019-0370

Urban, B., \& Chantson, J. (2019). Academic Entrepreneurship in South Africa: Testing for Entrepreneurial Intentions. The Journal of Technology Transfer, 44, 948-980.

https://doi.org/10.1007/s10961-017-9639-Z

Vracheva, V., \& Stoyneva, I. (2020). Does Gender Equality Bridge or Buffer the Entrepreneurship Gender Gap? A Cross-Country Investigation. International Journal of Entrepreneurial Behavior and Research, 26, 1827-1844.

https://doi.org/10.1108/IJEBR-03-2020-0144

Wibowo, S. F. (2019). Competing Extended TPB Models in Predicting. Academy of Entrepreneurship Journal, 25, 1-15.

Yamane, T. (1967). Statistics: An Introduction Analysis (2nd ed.). Harper and Row. 
Zhao, H., Seibert, S. E., \& Hills, G. E. (2005). The Mediating Role of Self-Eddicacy in the Development of Entrepreneurial Intentions. Journal of Applied Psychology, 90, 1265-1272. https://doi.org/10.1037/0021-9010.90.6.1265 